\title{
Palynological evidence for late Miocene stepwise aridification on the northeastern Tibetan Plateau
}

\author{
Jia Liu ${ }^{1}$, Ji Jun Li ${ }^{1}$, Chun Hui Song ${ }^{2}$, Hao Yu ${ }^{1}$, Ting Jiang Peng ${ }^{1}$, Zheng Chuang Hui ${ }^{1}$, and Xi Yan Ye ${ }^{1}$ \\ ${ }^{1}$ MOE Key Laboratory of Western China's Environmental Systems \& College of Earth and Environmental Sciences, \\ Lanzhou University, Lanzhou 730000, China \\ ${ }^{2}$ Key Laboratory of Western China's Mineral Resources of Gansu Province \& School of Earth Sciences, Lanzhou University, \\ Lanzhou 730000, China
}

Correspondence to: Ji Jun Li (lijj@lzu.edu.cn)

Received: 17 August 2015 - Published in Clim. Past Discuss.: 10 November 2015

Revised: 26 May 2016 - Accepted: 23 June 2016 - Published: 12 July 2016

\begin{abstract}
Holding a climatically and geologically key position both regionally and globally, the northeastern Tibetan Plateau provides a natural laboratory for illustrating the interactions between tectonic activity and the evolution of the Asian interior aridification. Determining when and how the late Miocene climate evolved on the northeastern Tibetan Plateau may help us better understand the relationships among tectonic uplift, global cooling and ecosystem evolution. Previous paleoenvironmental research has focused on the western Longzhong Basin. Late Miocene aridification data derived from pollen now require corroborative evidence from the eastern Longzhong Basin. Here, we present a late Miocene pollen record from the Tianshui Basin in the eastern Longzhong Basin. Our results show that a general trend toward dry climate was superimposed by stepwise aridification: a temperate forest with a rather humid climate existed in the basin between 11.4 and $10.1 \mathrm{Ma}$, followed by a temperate open forest environment with a less humid climate between 10.1 and 7.4 Ma, then giving way to an open temperate forest-steppe environment with a relatively arid climate between 7.4 and 6.4 Ma. The vegetation succession demonstrates that the aridification of the Asian interior occurred after $\sim 7-8 \mathrm{Ma}$, which is confirmed by other evidence from Asia. Furthermore, the aridification trend on the northeastern Tibetan Plateau parallels the global cooling of the late Miocene; the stepwise vegetation succession is consistent with the major uplift of the northeastern Tibetan Plateau during this time. These integrated environmental proxies indicate that the long-term global cooling and the Tibetan Plateau
\end{abstract}

uplift caused the late Miocene aridification of the Asian interior.

\section{Introduction}

As the latter stage of the global Cenozoic cooling, the Neogene was a critical period for northern hemispheric aridification, especially for the marked aridification of the Asian interior. Establishing when, and how, this process of aridification began and evolved is therefore vital for elucidating the interactions among tectonic uplift, global cooling and ecosystem evolution. Although there is compelling evidence for the aridification of the Asian interior, there is no consensus concerning its evolution and driving mechanisms. For instance, previous researchers have suggested that the aridification of the Asian interior began in the late Miocene, based particularly on biological and isotopic evidence (Andersson and Werdelin, 2005; Cerling et al., 1997; Dettman et al., 2001; Eronen et al., 2012; Quade et al., 1989; Wang and Deng, 2005; Zhang et al., 2012). However, others have argued that the process of Asian interior aridification may have begun in the early Miocene (22 Ma) or even earlier (in the late Oligocene), as inferred from Miocene or Oligocene eolian deposition (Guo et al., 2002, 2008; Qiang et al., 2011; Sun et al., 2010). The particular driving mechanisms of such aridification also remain enigmatic. Up until now, the tectonic uplift of the Tibetan Plateau (TP), global cooling and land-sea distributions have been suggested as the major drivers (An et al., 2001; Gupta et al., 2004; Kutzbach et al., 1993; Liu and Yin, 2002; Miao et al., 2012; Molnar et al., 2010). However, 

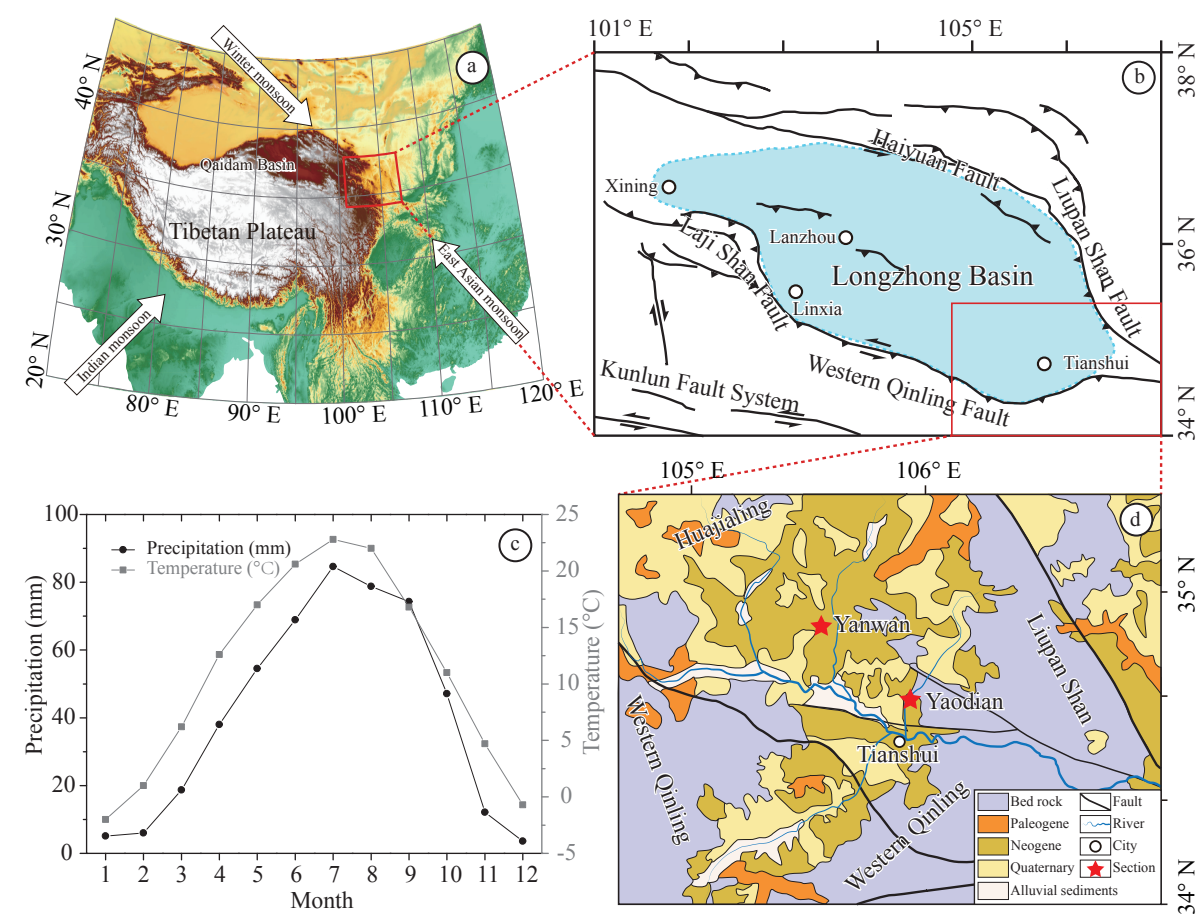

Figure 1. Geographic setting of Yaodian Section. (a) Location of the Longzhong Basin. (b) Major tectonic faults of the Longzhong Basin. (c) Mean monthly temperature and mean monthly precipitation in the Tianshui area, 1971-2000. (d) Geological map of the Tianshui Basin.

there is little consensus about which one is the most important driver. We focused on the region of the northeastern TP to explore the nature of the interactions between tectonics and climate.

The geographically extensive Longzhong Basin, consisting of a series of subbasins, is located in the northeastern TP. These subbasins present a continuous record of mammalian fossil-rich Cenozoic sediments, recording the effect of TP uplift on regional climates (Fang et al., 2003, 2005; GRGST, 1984; Li et al., 2006, 2014), as well as the effect of the global cooling. On the other hand, it lies in the so-called monsoonal triangle, a transition zone from a warm-humid Asian monsoonal climate to a dry-cold inland climate and to the alpine climate of the TP (Li et al., 1988, 2014) (Fig. 1a). Its particular geological and geographical characteristics make it sensitive to document the aridification history of northern China. As a field laboratory for studying tectonic-climate interactions (Molnar et al., 2010; Tapponnier et al., 2001), the Longzhong Basin might be the most promising for distinguishing TP uplift and associated environmental change.

As a reliable paleoenvironmental proxy, pollen has been used to reconstruct past climates because of its abundance and excellent preservation within sediments. Previous research has demonstrated that the Tianshui Basin, as a subbasin of the Longzhong Basin, exhibits a typical late Miocene lacustrine-fluvial sedimentary succession containing abundant pollen ( $\mathrm{Li}$ et al., 2006). Here we reconstruct a high-resolution palynological record from the well-dated
Yaodian Section, located in the southern part of the Tianshui Basin. Our results not only provide new evidence for the evolution of vegetation in the late Miocene and climate change on northeastern margin of the TP but also shed new light on the aridification of the Asian interior.

\section{Geological and geographical settings}

The rhomboid-shaped Longzhong Basin, which is one of the largest intermountain and fault-controlled sedimentary basins on the northeastern TP, is geographically delineated by the left-lateral strike-slip Haiyuan Fault to the north, the Liupan Shan Fault to the east and northeast, the Laji Shan Fault to the southwest, and the Western Qinling Fault to the south (Fig. 1b). The Tianshui Basin, one of its subbasins, is located in the southeastern part of the Longzhong Basin (Fig. 1b). It has witnessed the continuous deposition of mammalian fossil-rich Cenozoic sediments from the surrounding mountains; these sediments record the interactions between mountain uplift, erosion and climate change (Alonso-Zarza et al., 2009; Li et al., 2006; Liu et al., 2015; Peng et al., 2012, 2016). At present, the East Asian monsoon influences this region, engendering a semi-humid, warm-temperate, continental monsoon climate, characterized by relatively hot, humid summers and cold, dry winters. The mean annual temperature and mean annual precipitation of this area are $\sim 11^{\circ} \mathrm{C}$ and $492 \mathrm{~mm}$, respectively, with rainfall concentrated mainly in summer and autumn (Fig. 1c). The modern nat- 


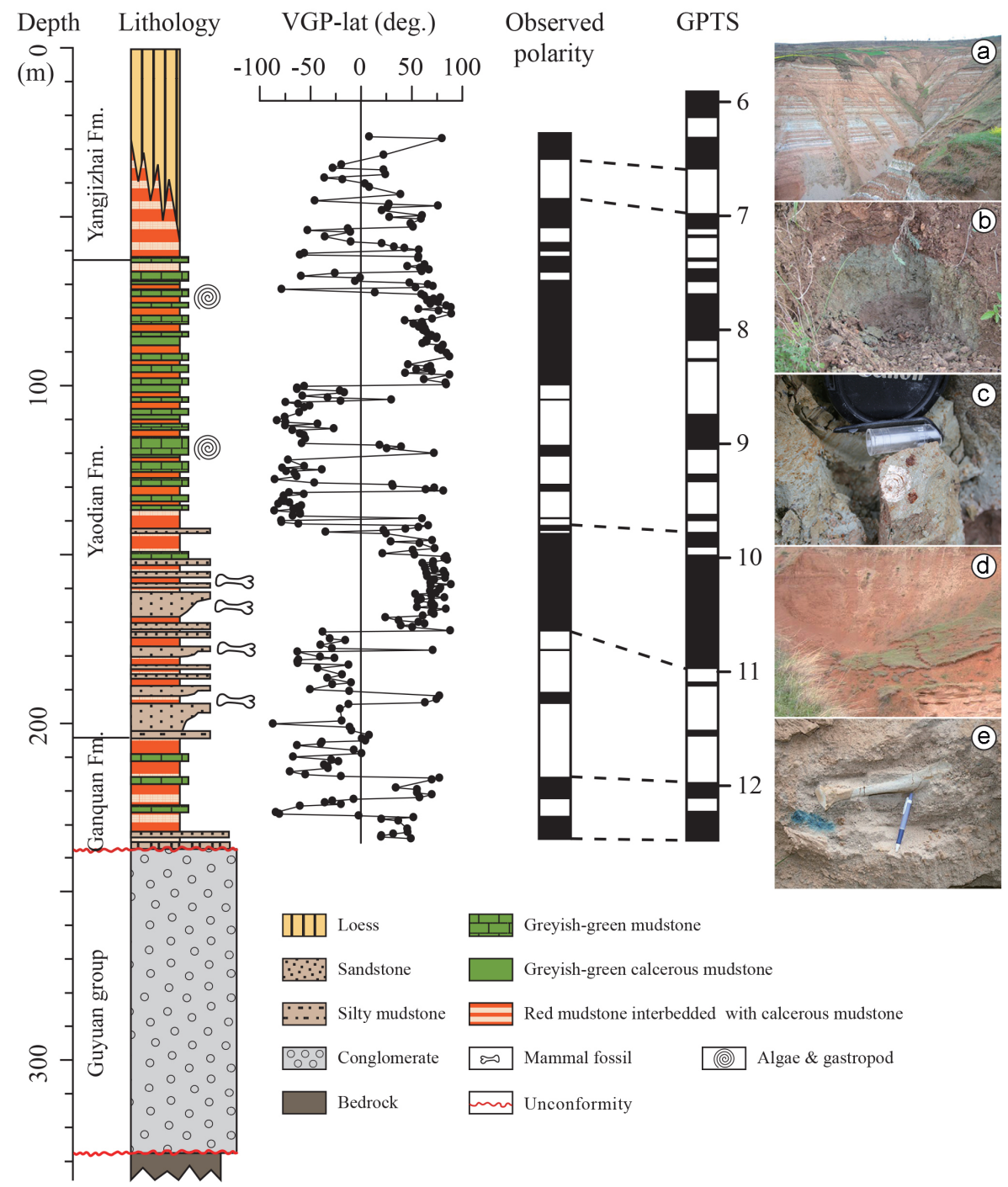

Figure 2. Lithology and magnetic stratigraphy of the Yaodian Section (according to Li et al., 2006). (a) The entire Yaodian Fm. (b) Yangjizhai Fm distal floodplain to palustrine deposits. (c) Yaodian Fm upper stratum lacustrine deposits, containing gastropod fossil fragments. (d) Yaodian Fm middle stratum floodplain deposits, with paleosols. (e) Yaodian Fm lower stratum fluvial channel deposits, containing fossilized animal bones. GTPS, standard geomagnetic polarity timescale in millions of years (Ma).

ural vegetation in this region is warm-temperature forestgrassland. Warm grasslands are distributed in the valleys, and consist mainly of Arundinella hirta, Spodiopogon sibiricus and Themeda triandran. Shrubs such as Zizyphus jujuba, Sophora viciifolia and Ostryopsis davidiana are found on the hillsides. Trees, including Quercus liaotungensis, Pinus tabulaeformis, $P$. armandi and Platycladus orientalis, grow in the mountains (Huang, 1997).

The selected Yaodian Section $\left(105^{\circ} 55^{\prime} \mathrm{E}, 34^{\circ} 38^{\prime} \mathrm{N}\right)$ is located in the southern part of the Tianshui Basin (Fig. 1d). The Neogene sequence in section is capped by loess and lies unconformably on top of the Paleogene Guyuan Group. It has been divided into the Ganquan Formation (Fm), the Yaodian Fm and the Yangjizhai Fm, in sequence upwards ( $\mathrm{Li}$ et al., 2006). In this study, our research mainly focuses on the late Miocene Yaodian Fm and Yangjizhai Fm. Based on a determination of lithology and sedimentology, the Yaodian Fm can be divided into three principal strata. The lower stratum consists of massive fine gravel sandstone, sandstone and brown silty mudstone, occasionally with thin brown mudstone or interbedded paleosols, which can be considered fluvial channel deposits (Fig. 2e). Abundant teeth of Hipparion weihoense, Cervavitus novorossiae, Ictitherium $\mathrm{sp}$. and their bone fragments were excavated from this stratum. The middle stratum of the Yaodian Fm consists of the interbedding of siltstone or fine sandstone with mudstone intercalated with paleosols, overlying the fluvial channel deposits. The assemblage's characteristics are typical of floodplain depo- 
sition (Fig. 2d). The upper stratum of the Yaodian Fm is characterized by rhythmic cycles composed of grey or brown mudstone or sandy marlite and intraclastic marl intercalated with brown siltstone and mudstone and contains fossil algae and gastropods; this section is representative of shallow lake deposition (Fig. 2a and c). The upper stratum is common throughout the basin, and is analogous to the "Zebra Bed" stratum found in the Linxia Basin in the western Longzhong Basin ( $\mathrm{Li}$ et al., 1995). The Yangjizhai Fm is principally composed of reddish-brown mudstone or silty mudstone and yellowish brown calcrete or calcareous mudstone, with scattered sandstone or grey mudstone and marlite. These sediments were deposited under strong evaporative conditions in distal floodplain to palustrine environments (Fig. 2b). Previous paleomagnetic investigations have indicated that the Yaodian Fm ranges from 11.67 to $7.43 \mathrm{Ma}$ in age, and that the Yangjizhai Fm dates from 7.43 to $6.40 \mathrm{Ma}$, with both of these ranges being consistent with the formations' biostratigraphic ages (Li et al., 2006).

\section{Materials and methods}

Most of the samples came from lacustrine mud deposits and fine grain size intercalations found in floodplain and fluvial channel deposits. Because the lower $10 \mathrm{~m}$ of the Yaodian Fm consists of coarse gravel sandstone, and it was difficult to find fine-grained sediments therein, this part of the formation was not sampled. A total of 200 samples were processed for palynological analysis. For each sample, $>100 \mathrm{~g}$ of sediment was washed in $20 \% \mathrm{HCl}$, soaked in $39 \% \mathrm{HF}$ and then treated with $10 \% \mathrm{HCl}$ solution to enable fluoride dissolution. We then concentrated pollen by physical enrichment procedures, using $\mathrm{ZnCl}_{2}$ separation and ultrasound sieving over a $10 \mu \mathrm{m}$ filter. Samples were stored in glycerin. Identifications were based on atlas of pollen and spores (Wang, 1995; Song, 1999), as well as modern reference slides from the collection of the Laboratory of Sporopollen Analysis of the Geography Department of Lanzhou University. A palynological diagram was plotted using Tilia v2.0.b.4 (Grimm, 1993) and pollen-assemblage zones were constructed using stratigraphically constrained cluster analysis (CONISS) (Grimm, 1987).

\section{Results}

Only 126 of the 200 samples contained enough palynomorphs to provide reliable data; the remaining 74 possessed fewer than 300 identifiable grains and have not been included in the analysis. Most of the latter samples had been preserved under oxidizing conditions or had high carbonate content. Approximately 80 different palynomorphs were identified at family or genus level. Percentages were expressed on the total number of recognized taxa. Tree pollen consists mainly of Pinus, Cupressaceae and Ulmus, along with Quercus and Betula. Additionally, a number of subtropical plants pollen, such as Liquidambar, Pterocarya and Carya (which are no longer found in this area today), appear often in low abundance. Herbaceous pollen is mainly from Artemisia, Chenopodioideae, Poaceae and Asteraceae. Pollen from extremely drought-tolerant plants, such as Ephedra and Nitraria, only appear sporadically in single samples. In addition, the section also contains fern spores and Pediastrum colonies. A selection of the more important taxa is given in Fig. 3. CONISS (Grimm, 1987) yields three distinct zones, described from the bottom up as follows.

\subsection{Zone 1 (195.5-158.5 m, 11.4-10.1 Ma)}

Samples from this zone exhibit high percentages of tree pollen, averaging $75 \%$. Coniferous taxa are mainly $\mathrm{Pi}$ nus $(19 \%)$ and Cupressaceae (18\%), with smaller amounts of Picea and Cedrus. Ulmus (20\%) is the most common broadleaf tree pollen, accompanied by pollen of Betula (3\%), Quercus (2\%) and Salix (2\%). Other arboreal taxa are Juglans and Castanea, with $<2 \%$ each. Herbaceous taxa mainly include Artemisia (7\%), Chenopodioideae (6\%) and Poaceae (2\%), along with small amounts of Asteraceae, Ranunculaceae and Rosaceae, with amounts of each $<2 \%$. Aquatic plants, algae and some subtropical taxa are also represented in this zone with low abundance.

\subsection{Zone 2 (158.5-63.5 m, 10.1-7.4 Ma)}

In this zone, total tree pollen percentage decreases, averaging $54 \%$. Coniferous taxa are principally represented by Pinus (14\%), Cupressaceae (7\%), Picea (2\%) and Cedrus (1\%). Among broadleaf trees, the dominant taxa are Ulmus (8\%), Quercus (2\%), Betula (2\%), Salix (2\%) and Juglans (1\%). Herbaceous taxa are dominated by Artemisia $(14 \%)$ and Chenopodioideae $(9 \%)$, along with Poaceae $(5 \%)$, Asteraceae $(3 \%)$ and Ranunculaceae $(3 \%)$. Aquatic vegetation reaches the highest value found in the entire profile. Subtropical taxa, such as Liquidambar, Pterocarya, Carya and Rutaceae, are represented with low abundance. The zone is divided into two subzones, Zone 2-1 (158.5-106.5 m, 10.18.6 Ma) and Zone 2-2 (106.5-63.5 m, 8.6-7.4 Ma). Herbaceous pollen percentages are slightly higher in Zone 2-2 than in Zone 2-1.

\subsection{Zone 3 (63.5-30 m, 7.4-6.4 Ma)}

The samples from this zone record a further decrease in tree pollen to an average value of $39 \%$. Coniferous taxa are characterized by Pinus (7\%) and Cupressaceae (5\%). Ulmus $(5 \%)$ dominates the broadleaf tree pollen, with Quercus and Betula each accounting for $2 \%$. Herbaceous taxa are composed of Artemisia (19\%), Chenopodioideae (11\%) and Poaceae $(9 \%)$, together with Asteraceae (5\%), Ranunculaceae (3\%), Brassicaceae (3\%) and Polygonaceae (2\%). Aquatic plants and thermophilic species almost disappear. 


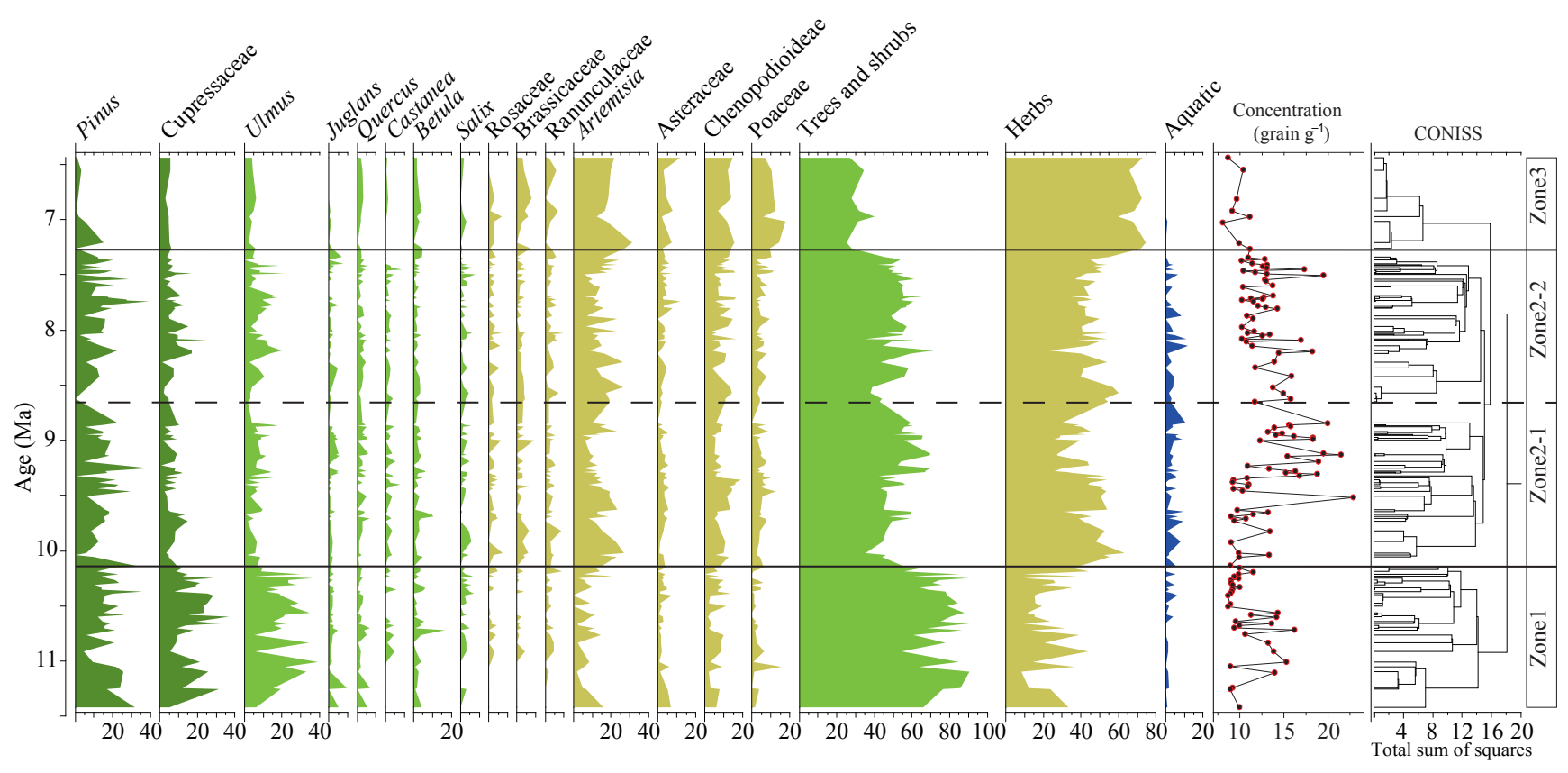

Figure 3. Histogram showing pollen percentages for the most significant angiosperms and gymnosperms.

\section{Discussion}

\subsection{Vegetation and climate reconstruction}

The sedimentary facies of the Yaodian Section indicate four successive depositional stages: fluvial channel, floodplain, shallow lake, and distal floodplain to palustrine. Transitionals can be dated to $10.4,9.23$ and $7.43 \mathrm{Ma}$ (Li et al., 2006) (Fig. 2). Our palynological record shows stepwise changes at 10.1 and $7.4 \mathrm{Ma}$, lagging slightly behind those evinced by the sedimentary facies. Another distinctive feature of the palynological record is that the green lacustrine deposits of fine grain size exhibit dense palynomorph concentrations, with higher tree pollen percentages. In contrast, the reddish floodplain deposits with coarse grain sizes possess sparse palynomorph concentrations, with higher herbaceous pollen percentages (Fig. 3). However, in the same pollen zones, we find that the palynomorph concentration clearly changes between different sedimentary facies, but that percentage fluctuations are minor. Between different pollen zones, the palynomorph percentages change strongly within the same sedimentary facies. We can therefore conclude that the changes in the palynological record are caused by changes in regional vegetation, rather than different preservation conditions. The paleoecological information inferred from the percentage change of pollen record can thus be considered reliable.

According to modern surface pollen studies, Pinus is often overrepresented in pollen records because of its abundant pollen production and the ease with which this pollen is transported over long distances. As a general rule, it can be assumed that there is/was no proximate pine forest if less than 25 to $30 \%$ of Pinus pollen occurs in samples ( $\mathrm{Li}$ and Yao, 1990). Higher percentages of Cupressaceae and Taxodiaceae coexistent with temperate tree, shrub and herbaceous pollen may reflect a warmer, wetter and more humid climate (Song, 1978). Nowadays, Ulmus is commonly distributed in the subhumid temperate and warm-temperate mountain foothills of northern China, but percentages of its pollen collected from the Chinese Loess Plateau surface soils never exceed $1 \%$, even under broadleaved forests containing elm (Liu et al., 1999). In general, when their abundance exceeds $3-5 \%$ of the arboreal pollen total, birch and oak can be considered to be/have been present in woodland (Liu et al., 1999). Salix produces very little pollen, and most of this pollen falls near the tree itself ( $\mathrm{Li}$ et al., 2000). Modern Artemisia and Chenopodioideae are extensively distributed throughout the arid and semi-arid regions of China. Chenopodioideae are more drought-resistant than Artemisia. Higher percentages of Artemisia pollen may reflect a semiarid grassland environment, while higher percentages of Chenopodioideae pollen may reflect an arid desert environment. Surface pollen analysis shows that Artemisia and Chenopodioideae are greatly overrepresented in the pollen rain. Only when Chenopodioideae and Artemisia pollen abundance exceeds $30 \%$ of the total should their presence be considered primarily local (Herzschuh et al., 2003; Ma et al., 2008). Poaceae pollen abundance is sparse, usually only 3-6\%, even when it represents the dominant modern species (Tong et al., 1995).

Our record therefore indicates that, during the period when the Yaodian Fm was being deposited, the study area was covered by temperate forests and a warm and humid cli- 


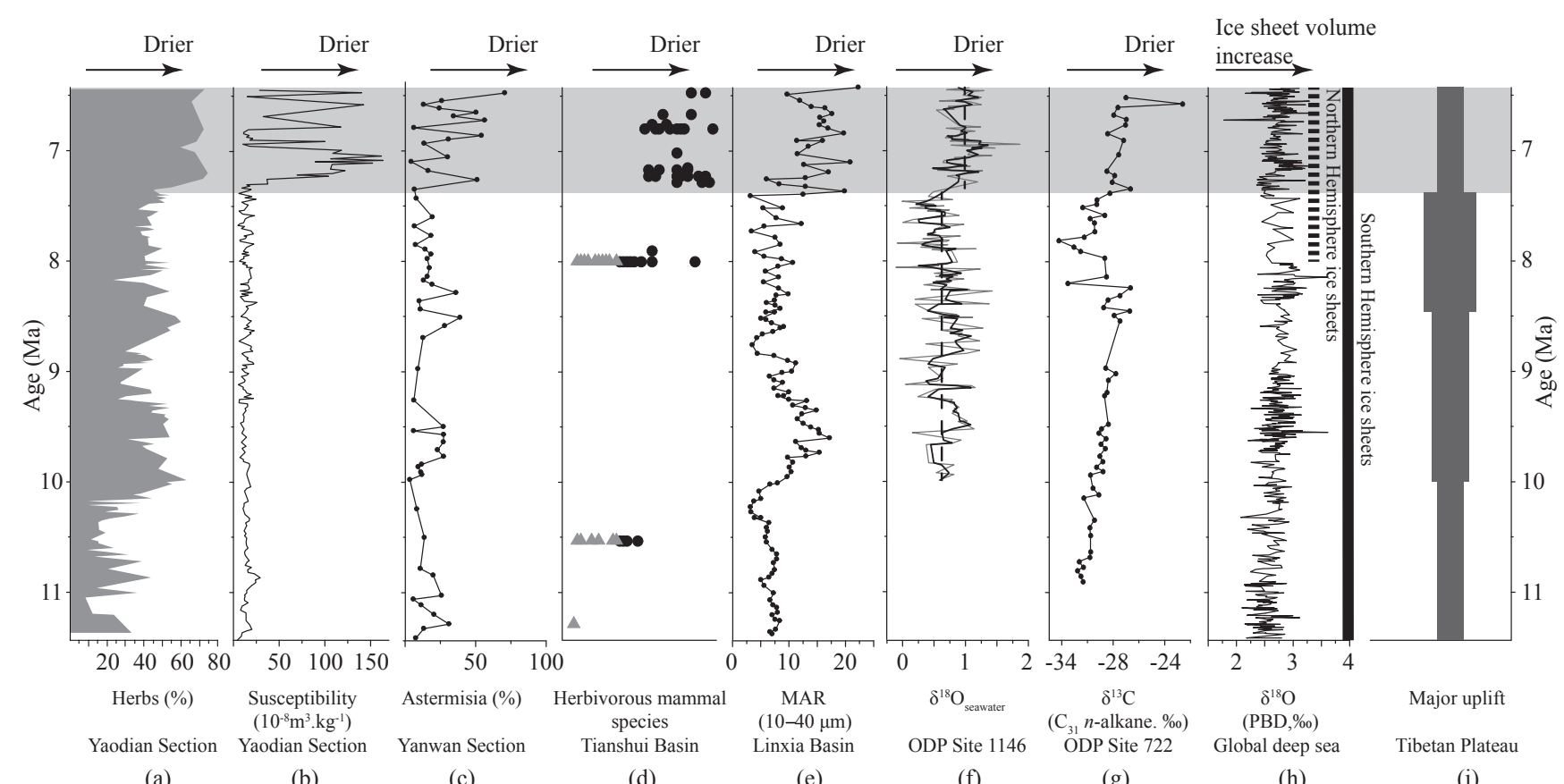

(a) (b)

(c)

(d)

(e)

(f)

(g)

(h)

(i)

Figure 4. Proxy records of aridification for East Asia during the late Miocene. (a) Herbaceous pollen percentage for the Yaodian Section (this study). (b) The magnetic susceptibility of the Yaodian Section (Zhang, 2013). (c) Drought-tolerant Artemisia pollen percentage in the Yanwan Section, northern Tianshui Basin (Hui et al., 2011). (d) Herbivorous mammal species in the Tianshui Basin (Guo et al., 2002; L. P. Liu et al., 2011; Li et al., 2006; Zhang et al., 2013). Black circles represent species which adapted to relatively arid environments, including Sinocricetus zdanskyi, Kowalskia sp., Hansdebmijnia pusillus, Lophocricetus grabaui, Mesosiphneus praetingi, M. sp., Paralactaga anderssoni, Parasoriculus sp., Prosiphneus eriksoni, P. licenti, P. tianzuensis, Prospermophilus orientalis, Pseudomeriones abbreuuuus, P. complicidens, Sicista sp., Alilepus annectens, Allorattus sp., Apodemus sp., Chardina sp., C. sinensis, C. truncatus, Chardinomys nihowanicus, C. sp., C. yusheensis, Pliosiphneus lyratus, Cricetinus mesolophidus, Mimomys teilhardi, Sinotamias sp., Ochotona gracilis, O. lagreli, O. lingtaica, O. minor, O. plicodenta, O. sp., Ochotonoma sp., O. primitiva, Trischizolagus mirificus, Hipparion chiai, H. dermatorhinum, $H$.fossatum, H.plocodus, H. sp., H. weihoense, and Gazella sp.; grey triangles represent species which adapted to relatively humid environments, including Chleuastochoerus stehlini, Cervavitus novorossiae, Cervidae gen. et sp. indet., Palaeotragus microdon, P. sp., Samotherium sinense, S. sp., Rhinocerotidae indet., Acerorhinus fuguebsis, Chilotherium habereri, $C$. sp., C. wimani and Protanancus tobieni. (e) Eolian sediment mass accumulation rates in the Linxia Basin, northeastern TP (Fan et al., 2006). (f) South China Sea $\delta^{18} \mathrm{O}_{\text {seawater }}$ estimate from ODP Site 1146 (Steinke et al., 2010). (g) Carbon isotope ratios of leaf wax $C_{31} n$-alkane extract from ODP Site 722 (Huang et al., 2007). (h) Compiled global deep-sea $\delta^{18} \mathrm{O}$ values (Zachos et al., 2001, data available online at http://www.es.ucsc.edu/ jzachos/Publications.html; a new compilation has been published by Mudelsee et al., 2014, which is congruent with the Zachos' curve for the Miocene part). (i) Schematic model showing the major periods of TP uplift (Enkelmann et al., 2006; Fang et al., 2003, 2005; Lease et al., 2007; Li et al., 2014; Molnar et al., 2010; Wang et al., 2006; X. X. Wang et al., 2012; Zheng et al., 2006, 2010).

mate. Mixed deciduous forests, characterized by the dominance of Pinus, Cupressaceae, Ulmus and Quercus, were distributed within the basin and the low-altitude hills surrounding it. Mid- and high-altitude forests with Abies, Picea and Cedrus existed in the surrounding uplands. The river banks or lake margins were colonized by Salix, Alnus, Fraxinus and Taxodiaceae. Cyperaceae, Typha and Myriophyllum grew along the lake shores or in shallow water areas. Ranunculaceae, Poaceae, Chenopodioideae and Artemisia principally occupied the forest understory and glade. However, as indicated by our record, the environment was not static. During 11.4-10.1 Ma, temperate forest grew in the basin, indicating a rather humid climate. The growth of fluvial channel deposits and the presence of a large number of mammalian fossils ( $\mathrm{Li}$ et al., 2006) also support the theory that much denser vegetation capable of supporting large mammals such as rhinoceroses developed during this interval. Moreover, we know that the northern Tianshui Basin was dominated by temperate and warm-temperate deciduous broadleaf forest (Hui et al., 2011). Our result is also consistent with research into the climatic evolution of the Qaidam Basin, which found that the presence of $\delta^{18} \mathrm{O}$ values characteristic of large mammals indicated a warmer, wetter, and perhaps lower-altitude Qaidam Basin (Zhang et al., 2012). The early late Miocene mammal fauna discovered in the Qaidam Basin also reflects a wooded environment, in which many streams with aquatic plants such as Trapa and Typha developed (Wang et al., 2007). From 10.1 to $7.4 \mathrm{Ma}$, the study area was dominated 
by a warm-temperate open forest environment and a less humid climate, relative to the previous interval. Sedimentary facies become characteristic of shallow lake deposits ( $\mathrm{Li}$ et al., 2006). Mammal fauna identified in the eastern Qaidam Basin also indicates that a mixed habitat of open and wooded environments, with abundant freshwater streams, was predominant at that time (Wang et al., 2007). In particular, herbaceous plants also increased their presence in the Tianshui Basin after $\sim 8.6 \mathrm{Ma}$, as confirmed by mammalian fossil records. In the northern Tianshui Basin at $\sim 9.5 \mathrm{Ma}$, there is evidence of a sizeable rhinoceros population, which would have required a relatively moist woodland environment to sustain itself. However, the typical Hipparion fauna at $\sim 8.0 \mathrm{Ma}$ probably represents a relatively temperate climate with more mixed vegetation, i.e., an open forest environment rather than a vast, open landscape. Large mammals would still have been able to survive in such an environment (Zhang et al., 2013).

An open temperate forest-steppe environment developed in the study region, indicating significant aridification after $\sim 7.4 \mathrm{Ma}$. Grassland, composed principally of Poaceae, Artemisia and Chenopodioideae, developed in most of the basin, while shrinking areas of open forest, dominated by $\mathrm{Cu}$ pressaceae, Ulmus and Quercus, existed in the surrounding mountains. Salix continued to grow in relatively humid environments such as riverbanks. Distal floodplain to palustrine deposits now characterized the study area (Li et al., 2006). A sudden increase in magnetic susceptibility after $\sim 7.4 \mathrm{Ma}$ may indicate an arid environment (Zhang, 2013) (Fig. 4b). In the northern part of the Tianshui Basin, drought-tolerant Artemisia predominated after 7.4 Ma, further confirming the presence of a drier climate (Hui et al., 2011) (Fig. 4c). Additionally, the growing presence of grazer mammalian species at the end of the Miocene in the Tianshui Basin suggests that the local environment was principally occupied by grassland, with some woodland, and even some deserts (L. P. Liu et al., 2011) (Fig. 4d). Furthermore, the gradual increase in eolian sediments after 7.4 Ma in the Linxia Basin would indicate a period of intense desertification in central China (Fan et al., 2006) (Fig. 4e). Biomarker evidence from the Linxia Basin also indicates a distinct change in climate toward arid-cold conditions at $\sim 8 \mathrm{Ma}$ (Y. L. Wang et al., 2012). The isotopic compositions of herbivorous fossil teeth and paleosols from the Linxia Basin (Wang and Deng, 2005) and southwestern China (Biasatti et al., 2012) also indicate a shift to a drier, or seasonally drier, local climate. In the Qaidam Basin, Hipparion teilhardi fossils are characterized by slenderer distal limbs and are dated to the end of the Miocene, implying an adaptation by this animal to the open steppe environment (Deng and Wang, 2004). Marine sediments also indicate that the climate changed at this time. For example, local seawater $\delta^{18} \mathrm{O}$ reconstructions from ODP Site 1146 in the northern South China Sea suggest that the climate of east and south Asia shifted toward more arid conditions after $\sim 7.5 \mathrm{Ma}$ (Steinke et al., 2010) (Fig. 4f).

\subsection{More arid condition at the end of the Miocene and possible causes}

Based on the late Neogene Chinese mammalian fossils data, Zhang (2006) suggested that mammal communities in northern China were rather stable and uniform from $\sim 13 \mathrm{Ma}$ to the end of the Miocene $(\sim 7-8 \mathrm{Ma})$, and that differentiation between the humid fauna communities prevalent in eastern China and the dry fauna communities identified in western China occurred after the end of the Miocene. The diversity in Bovidae fossils also increases significantly toward the end of the Miocene, with some genera appearing in southwestern China (Chen and Zhang, 2009), indicating an expansion of grasslands and aridification. Using macro- and microfloral quantitative recovery techniques to reconstruct the climate in northern China at the time, Y.S. C. Liu et al. (2011) proposed that the west-east temperature and precipitation gradient pattern did not develop in northern China until the end of the Miocene. This corroborates the quantitative results gained from using mammalian fossils as a proxy for paleoprecipitation (Liu et al., 2009). A semi-quantitative reconstruction of Chinese Neogene vegetation also indicated that the aridification of western, central and northern China occurred during the Miocene-Pliocene transition (Jacques et al., 2013). Indeed, in order to adapt to the arid climate of northern China during the end of the Miocene, some plants and arthropods also evolved more aridtolerant species, such as Frutescentes (Fabaceae) (Zhang and Fritsch, 2010), Ephedra (Ephedraceae) (Qin et al., 2013) and Mesobuthus (Buthidae) (Shi et al., 2013). This marked aridification has been well documented in other parts of Asia. For example, dramatic changes in the carbon isotopic ratio of leaf waxes at ODP Site 722 indicate an increasing aridity at the end of the Miocene in continental source regions, including Pakistan, Iran, Afghanistan, and the Arabian Peninsula (Huang et al., 2007) (Fig. 4g). The isotopic compositions of herbivorous fossil teeth and paleosol carbonates also suggest that the climate became drier over the Indian Subcontinent, China, and central Asia toward the end of the Miocene (Badgley et al., 2008; Barry et al., 2002; Biasatti et al., 2012; Cerling et al., 1997; Quade et al., 1989; Wang and Deng, 2005; Zhang et al., 2009). The evidential synchronicity of these climatic events in Asia strongly suggests that the aridification of the Asian interior began at the end of the Miocene $(\sim 7-8 \mathrm{Ma})$. The onset of such a marked aridification is further corroborated by the presence of red clay across much of the Chinese Loess Plateau (An et al., 2001).

Precipitation in arid northwestern China is primarily caused by the Asian summer monsoon, whereas the Asian winter monsoon promotes a cold and dry climate. Besides the monsoon source, the westerlies also bring precipitation into China. During the Neogene, Eurasia was influenced by global cooling, land-sea redistribution and regional tectonic uplift (Lease et al., 2007; Li et al., 2014; Guo et al., 2008; Miao et al., 2013, 2016; Molnar et al., 2010; Mudelsee et al., 
2014; Zachos et al., 2001; Zhang et al., 2007), and these three factors are considered as the major drivers for the formation and evolution of the Asian monsoon and inland arid climate.

During the late Neogene, the most significant global cooling event occurred at $\sim 14 \mathrm{Ma}$ (Mudelsee et al., 2014; Zachos et al., 2001), followed by a longer-term but minor cooling trend (4-10 Ma; Mudelsee et al., 2014) (Fig. 4h). Although the global cooling should somehow lead to net aridification on the planet, cooling and aridification trends do not seem to run parallel (van Dam, 2006). The complexity of the atmospheric and oceanic circulation systems ensures that general cooling may result in a precipitation decrease in some regions and an increase in others (van Dam, 2006). However, integrated studies have showed that the global cooling during the Neogene had significant influences on driving the Asian monsoon and inland arid climate (e.g., Lu et al., 2010; Lu and Guo, 2014; Tang and Ding, 2013), especially since the late Miocene ( $\mathrm{Lu}$ and Guo, 2014). The possible mechanism lies in two aspects. Firstly, it is clear that the global cooling has strengthened the Siberia High, which dominates winter monsoon circulation and aridity in eastern Asia ( $\mathrm{Lu}$ and Guo, 2014). This would result in enhanced and more frequent cold surges in the mid-latitudes of the Northern Hemisphere. Secondly, the global cooling caused the weakening of hydrological cycle, expanding of ice sheets, lowering of sea level and increasing of continental surface ( $\mathrm{Lu}$ and Guo, 2014; Tang and Ding, 2013). This would reduce the moisture mass transported into the continental interior (Tang and Ding, 2013). Therefore, we speculate that the global cooling could intensify aridity of the Asian interior.

Besides the above focusing on the climate effects of the global cooling, model simulations have paid special attention to the climatic effects of the land-sea redistribution. For example, model simulations suggest that the westward retreat of the Paratethys from central Asia has contributed significantly to Asian climates (e.g., Guo et al., 2008; Ramstein et al., 1997; Zhang et al., 2007). However, a large amount of geological evidence suggests that the vast majority, or even all, of the Paratethys regression from the Tarim Basin (northwestern China) occurred at the Oligocene (e.g., Bershaw et al., 2012; Bosboom et al., 2014). At the same time, numerical simulation also indicates that the spreading of the South China Sea may enhance the south-north contrast of humidity in China (Guo et al., 2008), bringing more precipitation into Asia. Nevertheless, many studies indicate that western and northern China became drier during the Neogene (e.g., Guo et al., 2008; Tang and Ding, 2013; Sun and Wang, 2005). Therefore, although the land-sea redistribution had a significant impact on the major climate reorganization in Asia during the late Oligocene/early Miocene (Guo et al., 2008; Zhang et al., 2007), it should have a limited effect on the formation and development of the Asian inland arid climate during the late Miocene.

Model simulations have also paid attention to the climate effects of the TP uplift. The scenarios of whole-plateau up- lift (e.g., Kutzbach et al., 1993), phased uplift (e.g., An et al., 2001; Kitoh, 2004; Liu and Yin, 2002) and subregional uplift (e.g., Boos and Kuang, 2010, 2013; Chen et al., 2014; Tang et al., 2011, 2013; Wu et al., 2012), with increasing complexity, are usually designed for discovering the cause-effect relations between the plateau uplift and paleoclimate change (Liu and Yin, 2011). The different models conclude that the uplift of the TP played an essential role in affecting the atmospheric circulation and forming the monsoon and arid climate when the whole/subregional plateau exceeds a critical height (An et al., 2001; Boos and Kuang, 2010, 2013; Chen et al., 2014; Kutzbach et al., 1993; Liu and Yin, 2002; Tang et al., 2011, 2013; Wu et al., 2012). However, because of the different model setups and boundary conditions, there still exist many uncertainties in the different forms of the plateau uplift forcing and regional climatic responses (Liu and Yin, 2011). The geological/proxy research can provide the constraints for the model boundary conditions, whereas numerical simulation can test the geological/proxy result. Therefore, it is useful to compare the geological/proxy results and the numerical simulations (Micheels et al., 2007, 2011). Many geological studies have suggested that the TP experienced rapid uplift during the interval $\sim 8-10 \mathrm{Ma}$ (e.g., Enkelmann et al., 2006; Fang et al., 2003, 2005; Lease et al., 2007; Li et al., 2014; Molnar et al., 2010; Wang et al., 2006; X. X. Wang et al., 2012; Zheng et al., 2006, 2010) (Fig. 4i), but the timing and degree of the uplift are still debated. The late Miocene uplift would have achieved an altitude sufficient to block the penetration of moisture from the source region into western China (Dettman et al., 2001, 2003). There is also increasing proxy evidence that the Asian summer monsoon weakened after $\sim 10 \mathrm{Ma}$ (e.g., Clift et al., 2008; Wan et al., 2010), while the Asian winter monsoon strengthened, particularly toward the end of the Miocene (e.g., An et al., 2001; Clift et al., 2008; Jacques et al., 2013; Jia et al., 2003; Sun and Wang, 2005), implying the involvement of intensified Asian inland aridification. It is consistent with the most model simulations that aridity of the Asian interior will be intensified along with the uplift of the TP. However, it should be noted that there is no doubt regarding the effects of the global cooling on the general trend toward a dry climate in the Asian interior.

\section{Conclusions}

The late Cenozoic basins, located at the northeast TP, document the environmental changes associated with tectonic uplift and global cooling. We investigate a late Miocene pollen record from the Tianshui Basin. Our results indicate that a temperate forest with a rather humid climate regime (11.4$10.1 \mathrm{Ma}$ ) gave way to a temperate open forest environment with a less humid climate (10.1-7.4 Ma); this was in turn replaced by an open temperate forest-steppe landscape, accompanied by a relatively arid climate (7.4-6.4 Ma). The vegetation succession demonstrates that the aridification of 
the Asian interior occurred after $\sim 7-8 \mathrm{Ma}$, as corroborated by other studies of Asia. Our findings support the idea that the long-term global cooling and the TP uplift caused the late Miocene aridification of the Asian interior.

\section{Data availability}

Data used in this study can be found in the Supplement.

\section{The Supplement related to this article is available online at doi:10.5194/cp-12-1473-2016-supplement.}

Acknowledgements. We thank Q. Y. Cui and Y. Z. Ma for their early pollen work, and L. Dupont and an anonymous reviewer for their valuable comments and suggestions. This work was cosupported by the State Key Program of National Natural Sciences of China (grant no. 41330745), the (973) National Basic Research Program of China (grant no. 2013CB956403) and the National Natural Science Foundation of China (grant nos. 41301216, 41272128 and 41201005).

Edited by: A. Paul

Reviewed by: L. Dupont and one anonymous referee

\section{References}

Alonso-Zarza, A. M., Zhao, Z. J., Song, C. H., Li, J. J., Zhang, J., Martín-Pérez, A., Martín-García, R. ,Wang, X. X., Zhang, Y., and Zhang, M. H.: Mudflat/distal fan and shallow lake sedimentation (upper Vallesian-Turolian) in the Tianshui Basin, Central China: evidence against the late Miocene eolian loess, Sediment. Geol., 222, 42-51, 2009.

An, Z. S., Kutzbach, J. E., Prell, W. L., and Porter, S. C.: Evolution of Asian monsoons and phased uplift of the Himalaya-Tibetan plateau since Late Miocene times, Nature, 411, 62-66, 2001.

Andersson, K. and Werdelin, L.: Carnivora from the late miocene of Lantian, China, Vertebrat. Palasiatic., 43, 256-271, 2005.

Badgley, C., Barry, J. C., Morgan, M. E., Nelson, S. V., Behrensmeyer, A. K., Cerling, T. E., and Pilbeam, D.: Ecological changes in Miocene mammalian record show impact of prolonged climatic forcing, P. Natl. Acad. Sci. USA, 105, 12145-12149, 2008.

Barry, J. C., Morgan, M. E., Flynn, L. J., Pilbeam, D., Behrensmeyer, A. K., Raza, S. M., Khan, I. A., Badgley, C., Hicks, J., and Kelley, J.: Faunal and environmental change in the late Miocene Siwaliks of northern Pakistan, Paleobiology, 28, 1-71, 2002.

Bershaw, J., Garzione, C. N., Schoenbohm, L., Gehrels, G., and Tao, L.: Cenozoic evolution of the Pamir plateau based on stratigraphy, zircon provenance, and stable isotopes of foreland basin sediments at Oytag (Wuyitake) in the Tarim Basin (west China), J. Asian Earth Sci., 44, 136-148, 2012.

Biasatti, D., Wang, Y., Gao, F., Xu, Y. F., and Flynn, L.: Paleoecologies and paleoclimates of late cenozoic mammals from Southwest China: evidence from stable carbon and oxygen isotopes, $\mathrm{J}$. Asian Earth Sci., 44, 48-61, 2012.
Boos, W. R. and Kuang, Z. M.: Dominant control of the South Asian monsoon by orographic insulation versus plateau heating, Nature, 463, 218-222, 2010.

Boos, W. R. and Kuang, Z. M.: Sensitivity of the South Asian monsoon to elevated and non-elevated heating, Sci. Rep.-Uk, 3 , doi:10.1038/srep01192, 2013.

Bosboom, R., Dupont-Nivet, G., Grothe, A., Brinkhuis, H., Villa, G., Mandic, O., Stoica, M., Kouwenhoven, T., Huang, W. T, Yang, W., and Guo, Z. J.: Timing, cause and impact of the late Eocene stepwise sea retreat from the Tarim Basin (west China), Palaeogeogr. Palaeocl., 403, 101-118, 2014.

Cerling, T. E., Harris, J. M., MacFadden, B. J., Leakey, M. G., Quade, J., Eisenmann, V., and Ehleringer, J. R.: Global vegetation change through the Miocene/Pliocene boundary, Nature, 389, 153-158, 1997.

Chen, G. F. and Zhang, Z. Q.: Taxonomy and evolutionary process of Neogene Bovidae from China, Vertebrat. Palasiatic., 10, 265 281, 2009.

Chen, G.-S., Liu, Z., and Kutzbach, J. E.: Reexamining the barrier effect of the Tibetan Plateau on the South Asian summer monsoon, Clim. Past, 10, 1269-1275, doi:10.5194/cp-10-1269-2014, 2014.

Clift, P. D., Hodges, K. V., Heslop, D., Hannigan, R., Van Long, H., and Calves, G.: Correlation of Himalayan exhumation rates and Asian monsoon intensity, Nat. Geosci., 1, 875-880, 2008.

Deng, T. and Wang, X. M.: Late Miocene Hipparion (Equidae, Mammalia) of eastern Qaidam Basin in Qinghai, China, Vertebrat. Palasiatic., 42, 316-333, 2004.

Dettman, D. L., Kohn, M. J., Quade, J., Ryerson, F. J., Ojha, T. P., and Hamidullah, S.: Seasonal stable isotope evidence for a strong Asian monsoon throughout the past $10.7 \mathrm{myr}$, Geology, 29, 3134, 2001.

Dettman, D. L., Fang, X. M., Garzione, C. N., and Li, J. J.: Upliftdriven climate change at $12 \mathrm{Ma}$ : a long $\delta^{18} \mathrm{O}$ record from the $\mathrm{NE}$ margin of the Tibetan plateau, Earth Planet. Sc. Lett., 214, 267277, 2003.

Enkelmann, E., Ratschbacher, L., Jonckheere, R., Nestler, R., Fleischer, M., Gloaguen, R., Hacker, B. R., Zhang, Y. Q., and Ma, Y. S.: Cenozoic exhumation and deformation of northeastern Tibet and the Qinling: is Tibetan lower crustal flow diverging around the Sichuan Basin?, Geol. Soc. Am. Bull., 118, 651-671, 2006.

Eronen, J. T., Fortelius, M., Micheels, A., Portmann, F. T., Puolamäki, K., and Janis, C. M.: Neogene aridification of the Northern Hemisphere, Geology, 40, 823-826, 2012.

Fan, M. J., Song, C. H., Dettman, D. L., Fang, X. M., and Xu, X. H.: Intensification of the Asian winter monsoon after 7.4 Ma: grain-size evidence from the Linxia Basin, northeastern Tibetan Plateau, 13.1 to 4.3 Ma, Earth Planet. Sc. Lett., 248, 186-197, 2006.

Fang, X. M., Garzione, C., Van der Voo, R., Li, J. J., and Fan, M. J.: Flexural subsidence by $29 \mathrm{Ma}$ on the NE edge of Tibet from the magnetostratigraphy of Linxia Basin, China, Earth Planet. Sc. Lett., 210, 545-560, 2003.

Fang, X. M., Yan, M. D., Van der Voo, R., Rea, D. K., Song, C. H., Parés, J. M., Gao, J. P., Nie, J. S., and Dai, S.: Late Cenozoic deformation and uplift of the NE Tibetan Plateau: evidence from high-resolution magnetostratigraphy of the Guide Basin, Qinghai Province, China, Geol. Soc. Am. Bull., 117, 1208-1225, 2005. 
Gansu Regional Geological Survey Team (GRGST): The tertiary system of Gansu province, in: Gansu Geology, People's Press of Gansu, Lanzhou, China, 1-40, 1984.

Grimm, E. C.: CONISS: a FORTRAN 77 program for stratigraphically constrained cluster analysis by the method of incremental sum of squares, Comput. Geosci., 13, 13-15, 1987.

Grimm, E. C.: TILIA Version 2.0.b.4, Illinois State Museum, Springfield, Illinois, USA, 1993.

Guo, Z. T., Ruddiman, W. F., Hao, Q. Z., Wu, H. B., Qiao, Y. S., Zhu, R. X., Peng, S. Z., Wei, J. J., Yuan, B. Y., and Liu, T. S.: Onset of Asian desertification by 22Myr ago inferred from loess deposits in China, Nature, 416, 159-163, 2002.

Guo, Z. T., Sun, B., Zhang, Z. S., Peng, S. Z., Xiao, G. Q., Ge, J. Y., Hao, Q. Z., Qiao, Y. S., Liang, M. Y., Liu, J. F., Yin, Q. Z., and Wei, J. J.: A major reorganization of Asian climate by the early Miocene, Clim. Past, 4, 153-174, doi:10.5194/cp-4-1532008, 2008.

Gupta, A. K., Singh, R. K., Joseph, S., and Thomas, E.: Indian Ocean high-productivity event (10-8 Ma): linked to global cooling or to the initiation of the Indian monsoons?, Geology, 32, 753-756, 2004.

Herzschuh, U., Kürschner, H., and Ma, Y. Z.: The surface pollen and relative pollen production of the desert vegetation of the Alashan Plateau, western Inner Mongolia, Chinese Sci. Bull., 48, 14881493, 2003.

Huang, D. S.: Vegetation of Gansu Province, Science and Technology of Gansu, Science and Technology of Gansu Press, Lanzhou, China, 1997.

Huang, Y. S., Clemens, S. C., Liu, W. G., Wang, Y., and Prell, W. L.: Large-scale hydrological change drove the late Miocene $\mathrm{C}_{4}$ plant expansion in the Himalayan foreland and Arabian Peninsula, Geology, 35, 531-534, 2007.

Hui, Z. C., Li, J. J., Xu, Q. H., Song, C. H., Zhang, J., Wu, F. L., and Zhao, Z. J.: Miocene vegetation and climatic changes reconstructed from a sporopollen record of the Tianshui Basin, NE Tibetan Plateau, Palaeogeogr. Palaeocl., 308, 373-382, 2011.

Jacques, F. M. B., Shi, G., and Wang, W. M.: Neogene zonal vegetation of China and the evolution of the winter monsoon, Bull. Geosci., 88, 175-193, 2013.

Jia, G. D., Peng, P. A., Zhao, Q. H., and Jian, Z. M.: Changes in terrestrial ecosystem since $30 \mathrm{Ma}$ in East Asia: stable isotope evidence from black carbon in the South China Sea, Geology, 31, 1093-1096, 2003.

Kitoh, A.: Effects of mountain uplift on East Asian summer climate investigated by a coupled atmosphere-ocean GCM, J. Climate, 17, 783-802, 2004.

Kutzbach, J. E., Prell, W. L., and Ruddiman, W. F.: Sensitivity of Eurasian climate to surface uplift of the Tibetan Plateau, J. Geol., 101, 177-190, 1993.

Lease, R. O., Burbank, D. W., Gehrels, G. E., Wang, Z. C., and Yuan, D. Y.: Signatures of mountain building: detrital zircon U/Pb ages from northeastern Tibet, Geology, 35, 239-242, 2007.

Li, J. J., Feng, Z. D., and Tang, L. Y.: Late Quaternary monsoon patterns on the Loess Plateau of China, Earth Surf. Proc. Land., 13, 125-135, 1988.

Li, J. J., Fang, X. M., Wang, J. L., Zhong, W., Cao, J. X., Pan, B. T., Ma, H. Z., Zhu, J. J., Zhou, S. Z., Chen, F. H., Wang, J. M., Ma, Y. Z., and Zhang, Y. C.: Uplift of Qinghai-Xizang (Tibet)
Plateau and global change, Lanzhou University Press, Lanzhou, China, 1995.

Li, J. J., Zhang, J., Song, C. H., Zhao, Z. J., Zhang, Y., and Wang, X. $\mathrm{X}$.: Miocene Bahean stratigraphy in the Longzhong Basin, northern central China and its implications in environmental change, Sci. China Ser. D, 49, 1270-1279, 2006.

Li, J. J., Fang, X. M., Song, C. H., Pan, B. T., Ma, Y. Z., and Yan, M. D.: Late Miocene-Quaternary rapid stepwise uplift of the NE Tibetan Plateau and its effects on climatic and environmental changes, Quaternary Res., 81, 400-423, 2014.

Li, W. Y. and Yao, Z. J.: A study on the quantitative relationship between Pinus pollen in surface sample and Pinus vegetation, Chinese Bulletin of Botany, 32, 943-950, 1990.

Li, Y. Y., Zhang, X. S., Zhou, G. S., and Ni, J.: The quantitative relationship between several common types of surface pollen and vegetation in northern China, Chinese Sci. Bull., 45, 761-765, 2000.

Liu, H. Y., Cui, H. T., Pott, R., and Speier, M.: The surface pollen of the woodland-steppe ecotone in southeastern Inner Mongolia, China, Rev. Palaeobot. Palyno., 105, 237-250, 1999.

Liu, L. P., Eronen, J. T., and Fortelius, M.: Significant midlatitude aridity in the middle Miocene of East Asia, Palaeogeogr. Palaeocl., 279, 201-206, 2009.

Liu, L. P., Zheng, S. H., Zhang, Z. Q., and Wang, L. H.: Late Miocene-Early Pliocene biostratigraphy and Miocene/Pliocene boundary in the Dongwan section, Gansu, Vertebrat. Palasiatic., 49, 229-240, 2011.

Liu, S. P., Li, J. J., Stockli, D. F., Song, C. H., Nie, J. S., Peng, T. J., Wang, X. X., He, K., Hui, Z. C., and Zhang, J.: Late Tertiary reorganizations of deformation in Northeastern Tibet constrained by stratigraphy and provenance data from Eastern Longzhong Basin, J. Geophys. Res.-Sol. Ea., 120, 5804-5821, 2015.

Liu, X. D. and Yin, Z. Y.: Sensitivity of East Asian monsoon climate to the uplift of the Tibetan Plateau, Palaeogeogr. Palaeocl., 183, 223-245, 2002.

Liu, X. D. and Yin, Z. Y.: Forms of the Tibetan Plateau uplift and regional differences of the Asian monsoon-arid environmental evolution-A modeling perspective, J. Earth Environ., 2, 401-416, 2011.

Liu, Y.-S. C., Utescher, T., Zhou, Z. K., and Sun, B. N.: The evolution of Miocene climates in North China: preliminary results of quantitative reconstructions from plant fossil records, Palaeogeogr. Palaeocl., 304, 308-317, 2011.

Lu, H. Y. and Guo, Z. T.: Evolution of the monsoon and dry climate in East Asia during late Cenozoic: A review, Science China Earth Sciences, 57, 70-79, 2014.

Lu, H. Y., Wang, X., and Li, L.: Aeolian sediment evidence that global cooling has driven late Cenozoic stepwise aridification in central Asia, Geological Society, London, Special Publications, 342, 29-44, 2010.

Ma, Y. Z., Liu, K., Feng, Z. D., Sang, Y. L., Wang, W., and Sun, A. Z.: A survey of modern pollen and vegetation along a southnorth transect in Mongolia, J. Biogeogr., 35, 1512-1532, 2008.

Miao, Y. F., Herrmann, M., Wu, F. L., Yan, X. L., and Yang, S. L.: What controlled Mid-Late Miocene long-term aridification in Central Asia? - Global cooling or Tibetan Plateau uplift: a review, Earth-Sci. Rev., 112, 155-172, 2012.

Miao, Y. F., Fang, X. M., Wu, F. L., Cai, M. T., Song, C. H., Meng, Q. Q., and $\mathrm{Xu}, \mathrm{L}$. : Late Cenozoic continuous aridification in 
the western Qaidam Basin: evidence from sporopollen records, Clim. Past, 9, 1863-1877, doi:10.5194/cp-9-1863-2013, 2013.

Miao, Y. F., Song, C. H., Fang, X. M., Meng, Q. Q., Zhang, P., Wu, F. L., and Yan, X. L.: Late Cenozoic genus Fupingopollenites development and its implications for the Asian summer monsoon evolution, Gondwana Res., 29, 320-333, 2016.

Micheels, A., Bruch, A. A., Uhl, D., Utescher, T., and Mosbrugger, V.: A Late Miocene climate model simulation with ECHAM4/ML and its quantitative validation with terrestrial proxy data, Palaeogeogr. Palaeocl., 253, 251-270, 2007.

Micheels, A., Bruch, A. A., Eronen, J., Fortelius, M., Harzhauser, M., Utescher, T., and Mosbrugger, V.: Analysis of heat transport mechanisms from a Late Miocene model experiment with a fullycoupled atmosphere-ocean general circulation model, Palaeogeogr. Palaeocl., 304, 337-350, 2011.

Molnar, P., Boos, W. R., and Battisti, D. S.: Orographic controls on climate and paleoclimate of Asia: thermal and mechanical roles for the Tibetan Plateau, Annu. Rev. Earth Pl. Sc., 38, 77-102, 2010.

Mudelsee, M., Bickert, T., Lear, C. H., and Lohmann, G.: Cenozoic climate changes: A review based on time series analysis of marine benthic $\delta^{18} \mathrm{O}$ records, Rev. Geophys., 52, 333-374, 2014.

Peng, T. J., Li, J. J., Song, C. H., Zhao, Z. J., Zhang, J., Hui, Z. C., and King, J. W.: Biomarkers challenge early Miocene loess and inferred Asian desertification, Geophys. Res. Lett., 39, L06702, doi:06710.01029/02012GL050934, 2012.

Peng, T. J., Li, J. J., Song, C. H., Guo, B. H., Liu, J., Zhao, Z. J., and Zhang, J.: An integrated biomarker perspective on NeogeneQuaternary climatic evolution in NE Tibetan Plateau: Implications for the Asian aridification, Quaternary Int., 399, 174-182, 2016.

Qiang, X. K., An, Z. S., Song, Y. G., Chang, H., Sun, Y. B., Liu, W. G., Ao, H., Dong, J. B., Fu, C. F., Wu, F., Lu, F. Y., Cai, Y. J., Zhou, W. J., Cao, J. J., Xu, X. W., and Ai, L.: New eolian red clay sequence on the western Chinese Loess Plateau linked to onset of Asian desertification about $25 \mathrm{Ma}$ ago, Sci. China Ser. D, 54, 136-144, 2011.

Qin, A. L., Wang, M. M., Cun, Y. Z., Yang, F. S., Wang, S. S., Ran, J. H., and Wang, X. Q.: Phylogeographic evidence for a link of species divergence of Ephedra in the Qinghai-Tibetan Plateau and adjacent regions to the Miocene Asian aridification, PLOS One, 8, e56243, doi:10.1371/journal.pone.0056243, 2013.

Quade, J., Cerling, T. E., and Bowman, J. R.: Development of Asian monsoon revealed by marked ecological shift during the latest Miocene in northern Pakistan, Nature, 342, 163-166, 1989.

Ramstein, G., Fluteau, F., Besse, J., and Joussaume, S.: Effect of orogeny, plate motion and land-sea distribution on Eurasian climate change over the past 30 million years, Nature, 386, 788795, 1997.

Shi, C. M., Ji, Y. J., Liu, L., Wang, L., and Zhang, D. X.: Impact of climate changes from Middle Miocene onwards on evolutionary diversification in Eurasia: insights from the mesobuthid scorpions, Mol. Ecol., 22, 1700-1716, 2013.

Song, Z. C.: Early Tertiary Sporopollen in Bohai Coastal Areas, Science Press, Beijing, China, 1978.

Song, Z. C.: Fossil Spores and Pollen of China: the Late Cretaceous and Tertiary Spores and Pollen, Science Press, Beijing, China, 1999.
Steinke, S., Groeneveld, J., Johnstone, H., and Rendle-Bühring, R.: East Asian summer monsoon weakening after 7.5 Ma: evidence from combined planktonic foraminifera $\mathrm{Mg} / \mathrm{Ca}$ and $\delta^{18} \mathrm{O}(\mathrm{ODP}$ Site 1146; northern South China Sea), Palaeogeogr. Palaeocl., 289, 33-43, 2010.

Sun, J. M., Ye, J., Wu, W. Y., Ni, X. J., Bi, S. D., Zhang, Z. Q., Liu, W. M., and Meng, J.: Late Oligocene-Miocene mid-latitude aridification and wind patterns in the Asian interior, Geology, 38, 515-518, 2010.

Sun, X. J. and Wang, P. X.: How old is the Asian monsoon system? Palaeobotanical records from China, Palaeogeogr. Palaeocl., 222, 181-222, 2005.

Tang, H., Micheels, A., Eronen, J., and Fortelius, M.: Regional climate model experiments to investigate the Asian monsoon in the Late Miocene, Clim. Past, 7, 847-868, doi:10.5194/cp-7-8472011, 2011.

Tang, H., Eronen, J. T., Micheels, A., and Ahrens, B.: Strong interannual variation of the Indian summer monsoon in the Late Miocene, Clim. Dynam., 41, 135-153, 2013.

Tang, Z. H. and Ding, Z. L.: A palynological insight into the Miocene aridification in the Eurasian interior, Palaeoworld, 22, 77-85, 2013

Tapponnier, P., Xu, Z. Q., Roger, F., Meyer, B., Arnaud, N., Wittlinger, G., and Yang, J. S.: Oblique stepwise rise and growth of the Tibet Plateau, Science, 294, 1671-1677, 2001.

Tong, G. B., Yang, X. D., Wang, S. M., and Xia, L. H.: Sporopollen dissemination and quantitative character of surface sample of Manzhouli-Dayangshu region, Acta Bot. Sin., 38, 814-821, 1995.

van Dam, J. A.: Geographic and temporal patterns in the late Neogene (12-3 Ma) aridification of Europe: the use of small mammals as paleoprecipitation proxies, Palaeogeogr. Palaeocl., 238, 190-218, 2006.

Wan, S. M., Clift, P. D., Li, A. C., Li, T. G., and Yin, X. B.: Geochemical records in the South China Sea: implications for East Asian summer monsoon evolution over the last $20 \mathrm{Ma}$, Geol. Soc. Sp., 342, 245-263, 2010.

Wang, F. X.: Pollen Flora of China, Science Press, Beijing, China, 1995.

Wang, X. M., Qiu, Z. D., Li, Q., Wang, B. Y., Qiu, Z. X., Downs, W. R., Xie, G. P., Xie, J. Y., Deng, T., Takeuchi, G. T., Tseng, Z. J., Chang, M., Liu, J., Wang, Y., Biasatti, D., Sun, Z. C., Fang, X. M., and Meng, Q. Q.: Vertebrate paleontology, biostratigraphy, geochronology, and paleoenvironment of Qaidam Basin in northern Tibetan Plateau, Palaeogeogr. Palaeocl., 254, 363-385, 2007.

Wang, X. X., Li, J. J., Song, C. H., Zattin, M., Zhao, Z. J., Zhang, J., Zhang, Y., and He, K.: Late Cenozoic orogenic history of Western Qinling inferred from sedimentation of Tianshui basin, northeastern margin of Tibetan Plateau, Int. J. Earth Sci., 101, 13451356, 2012.

Wang, Y. and Deng, T.: A 25 myr isotopic record of paleodiet and environmental change from fossil mammals and paleosols from the NE margin of the Tibetan Plateau, Earth Planet. Sc. Lett., 236, 322-338, 2005.

Wang, Y., Deng, T., and Biasatti, D.: Ancient diets indicate significant uplift of southern Tibet after ca. 7 Ma, Geology, 34, 309312, 2006. 
Wang, Y. L., Fang, X. M., Zhang, T. W., Li, Y. M., Wu, Y. Q., He, D. X., and Gao, Y.: Distribution of biomarkers in lacustrine sediments of the Linxia Basin, NE Tibetan Plateau, NW China: significance for climate change, Sediment. Geol., 243, 108-116, 2012.

Wu, G. X., Liu, Y. M., He, B., Bao, Q., Duan, A. M., and Jin, F. F.: Thermal controls on the Asian summer monsoon, Sci. Rep.-Uk, 2, 404, doi:10.1038/srep00404, 2012.

Zachos, J., Pagani, M., Sloan, L., Thomas, E., and Billups, K.: Trends, rhythms, and aberrations in global climate $65 \mathrm{Ma}$ to present, Science, 292, 686-693, 2001.

Zhang, C. F., Wang, Y., Deng, T., Wang, X. M., Biasatti, D., Xu, Y. F., and $\mathrm{Li}, \mathrm{Q}$.: $\mathrm{C}_{4}$ expansion in the central Inner Mongolia during the latest Miocene and early Pliocene, Earth Planet. Sc. Lett., 287, 311-319, 2009.

Zhang, C. F., Wang, Y., Li, Q., Wang, X. M., Deng, T., Tseng, Z. J., Takeuchi, G. T., Xie, G. P., and Xu, Y. F.: Diets and environments of late Cenozoic mammals in the Qaidam Basin, Tibetan Plateau: evidence from stable isotopes, Earth Planet. Sc. Lett., 333, 7082, 2012.

Zhang, J.: Late Miocene climatic changes recorded by colors in the Yaodian section of the Tianshui Basin and its influencing factors, Science Paper Online, 201301-272, 1-10, 2013.

Zhang, J., Li, J. J., Song, C. H., Zhao, Z. J., Xie, G. P., Wang, X. X., Hui, Z. C., and Peng, T. J.: Paleomagnetic ages of Miocene fluvio-lacustrine sediments in the Tianshui Basin, western China, J. Asian Earth Sci., 62, 341-348, 2013.
Zhang, M. L. and Fritsch, P. W.: Evolutionary response of Caragana (Fabaceae) to Qinghai-Tibetan Plateau uplift and Asian interior aridification, Plant Syst. Evol., 288, 191-199, 2010.

Zhang, Z. Q.: Chinese Late Neogene land mammal community and the environmental changes of East Asia, Vertebrat. Palasiatic., 44, 133-142, 2006.

Zhang, Z. S., Wang, H. J., Guo, Z. T., and Jiang, D. B.: What triggers the transition of palaeoenvironmental patterns in China, the Tibetan Plateau uplift or the Paratethys Sea retreat?, Palaeogeogr. Palaeocl., 245, 317-331, 2007.

Zheng, D. W., Clark, M. K., Zhang, P. Z., Zheng, W. J., and Farley, K. A.: Erosion, fault initiation and topographic growth of the North Qilian Shan (northern Tibetan Plateau), Geosphere, 6, 937-941, 2010.

Zheng, D. W., Zhang, P. Z., Wan, J. L., Yuan, D. Y., Li, C. Y., Yin, G. M., Zhang, G. L., Wang, Z. C., Min, W., and Chen, J.: Rapid exhumation at $\sim 8 \mathrm{Ma}$ on the Liupan Shan thrust fault from apatite fission-track thermochronology: implications for growth of the northeastern Tibetan Plateau margin, Earth Planet. Sc. Lett., 248, 198-208, 2006. 